\title{
Nuclear Factor Kappa B Inhibition Improves Conductance Artery Function in Type 2 Diabetic Mice
}

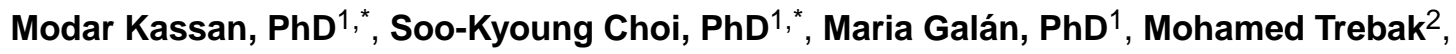

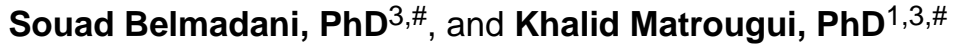 \\ ${ }^{1}$ Department of Physiology, Hypertension and Renal Center of Excellence, Tulane University, \\ 1430 Tulane Ave, New Orleans LA-70112 \\ ${ }^{2}$ College of Nanoscale Science and Engineering University at Albany 257 Fuller Rd. Albany, NY \\ 12203 \\ ${ }^{3}$ Department of Physiological Sciences, Eastern Virginia School of Medicine, 700 W Olney Rd, \\ Norfolk, Virginia 23501.
}

\begin{abstract}
Background-We previously reported that enhanced nuclear factor kappa $\mathrm{B}(\mathrm{NF \kappa B})$ activity is responsible for resistance arteries dysfunction in type 2 diabetic mice.

Methods-In this study we aimed to determine whether augmented NFkB activity also impairs conductance artery (thoracic aorta) function in type 2 diabetic mice. We treated type 2 diabetic $\left(\mathrm{db}^{-} / \mathrm{db}^{-}\right)$and control $\left(\mathrm{db}^{-} / \mathrm{db}^{+}\right)$mice with two NFKB inhibitors (DHMEQ, $6 \mathrm{mg} / \mathrm{kg}$, twice a week and IKK-NBD peptide, $500 \mu \mathrm{g} / \mathrm{kg} /$ day) for four weeks.
\end{abstract}

Results-As expected, the NFkB inhibition did not affect blood glucose level and body weight. Thoracic aorta vascular endothelium-dependent relaxation (EDR), determined by the wire myograph, was impaired in diabetic mice compared to control, and was significantly improved after $\mathrm{NF \kappa B}$ inhibition. Interestingly, thoracic EDR was also rescued in $\mathrm{db}^{-} / \mathrm{db}^{-\mathrm{p} 50 \mathrm{NF} \kappa \mathrm{B}-/-}$ and $\mathrm{db}$ $-/ \mathrm{db}^{\text {-PARP-1-l- }}$ double knockout mice compared to $\mathrm{db}^{-} / \mathrm{db}^{-}$mice. Similarly, the acute in vitro down regulation of NFkB-p65 using p65 shRNA lentiviral particles in arteries from $\mathrm{db}^{-} / \mathrm{db}^{-}$mice also improved thoracic aorta EDR. Western blot analysis showed that the $\mathrm{p} 65 \mathrm{NF} \kappa \mathrm{B}$ phosphorylation, cleaved PARP-1 and COX-2 expression were increased in thoracic aorta from diabetic mice, which were restored after $\mathrm{NF \kappa B}$ inhibition and in $\mathrm{db}^{-} / \mathrm{db}^{-\mathrm{p}-50 \mathrm{NF} \kappa \mathrm{B}-/-}$ and $\mathrm{db}^{-/ \mathrm{db}^{-P A R P}-1-/-}$ mice.

Conclusions-The present results indicate that in male type 2 diabetic mice, the augmented $\mathrm{NF} \kappa \mathrm{B}$ activity also impairs conductance artery function through PARP-1 and COX-2-dependent mechanisms.

\footnotetext{
\#Corresponding Authors: Khalid Matrougui, Ph.D. (matrouk@evms.edu) \& Souad Belmadani, PhD (belmads@evms.edu) Department of Physiological Sciences, 700 W Olney Rd, Norfolk, Virginia 23501. Phone: 757-446-5278. Fax: 757-624-2270..

*Dr. Kassan and Dr. Choi are co-first authors

Disclosures

None
} 


\section{Keywords}

Type 2 diabetes; NFkB; PARP-1; COX-2; Thoracic aorta; Endothelial function

\section{INTRODUCTION}

Diabetes is an established cardiovascular risk factor, affecting millions of people worldwide. Several factors such as metabolic factors, inflammation, glycation products and endothelial dysfunction, contribute to diabetes-induced cardiovascular diseases. The complication of microvascular and macrovascular function is a major cause of morbidity and mortality in diabetic patients [ 1,2 ]. Endothelial vascular dysfunction is mostly characterized by the impairment of eNOS signaling and/or decreased nitric oxide bioavailability $[3,4,5]$ associated with increases in activity of the pro-inflammatory transcription factor nuclear factor kappa B (NFkB) [3]. It was reported that enhanced $\mathrm{NF \kappa B}$ activity is an important factor involved in the development of cardiovascular diseases [6].

Previous studies indicate that hyperglycemia can trigger the induction of cyclooxygenases 2 (COX-2) and enhance NFkB activity [7]. Additionally, studies reported that COX-2 induction is primarily mediated through the activation of the NFkB pathway [ 8,9 ]. Furthermore, hyperglycemia also enhances Poly(ADP-ribose) Polymerase-1 (PARP-1)dependent $\mathrm{NF \kappa B}$ activation that is implicated in the expression of pro-inflammatory genes that are dependent on this transcription factor [10]. We recently elucidated that PARP-1 inhibition improves vascular function in type 2 diabetes indicating that PARP-1 could be a potential target for overcoming diabetic micro-vascular complications [11]. Additionally, previous studies suggested a role for PARP-1 activation in vascular dysfunction in type 2 diabetes $[12,13]$ Thus, the role and mechanism of $\mathrm{NF \kappa B}$ in conductance artery dysfunction in type 2 diabetes is an important question that remains unanswered. We recently demonstrated that enhanced $\mathrm{NFKB}$ in type 2 diabetic mice impairs resistance arteries endothelium-dependent relaxation [ 14 ]. Since the complication of vasculature in diabetes includes resistance and conductance arteries, we aimed to determine whether enhanced NFkB activity in type 2 diabetes also impairs endothelium-dependent relaxation in conductance arteries such thoracic aorta.

\section{MATERIALS AND METHODS}

\section{General protocol in mice}

All experiments were performed according to the American Guidelines for the Ethical Care of Animals and were approved by Tulane University Health Sciences Center Animal Care and Use Committee. Type 2 diabetic male mice ( $\mathrm{db}^{-} / \mathrm{db}^{-}, 8$ to 10 weeks-old males) and their homologous control were purchased from Jackson Laboratories (Bar Harbor, ME), housed in groups of five mice, and maintained at a temperature of $23^{\circ} \mathrm{C}$ with $12 \mathrm{~h} \mathrm{light/dark} \mathrm{cycles.}$ The mice were fed with Harlan Global 18\% Protein Rodent Diet (2018) containing 6.0\% fat, $18.0 \%$ protein and $3.1 \mathrm{Kcal} / \mathrm{g}$ in content. Mice were divided in 6 groups: 1$)$ control mice infused with saline, $\mathrm{n}=10$ ); 2) control mice who received DHMEQ (NFkB inhibitor, $6 \mathrm{mg} / \mathrm{kg}$ intra-peritoneal injection twice a week) for 4 weeks (Control + DHMEQ, n=10); 3) control 


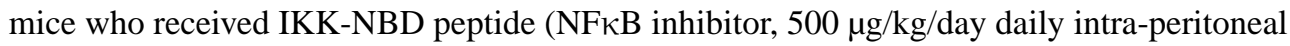
injection) for 4 weeks (Control + Peptide, $\mathrm{n}=10) ; 4)$ diabetic mice $\left(\mathrm{db}^{-} / \mathrm{db}^{-}\right.$mice infused with saline, $\mathrm{n}=10)$; 5) Diabetic mice treated with DHMEQ for 4 weeks $\left(\mathrm{db}^{-} / \mathrm{db}^{-}+\right.$DHMEQ, $\mathrm{n}=10)$; 6) Diabetic mice treated with IKK-NBD peptide for 4 weeks $\left(\mathrm{db}^{-} / \mathrm{db}^{-}+\right.$Peptide, $\mathrm{n}=10$ ). The body weight and blood glucose levels were recorded weekly during the experimental period. Blood glucose measurements were obtained from tail blood samples using a blood glucose meter (Prestige Smart System HDI; Home Diagnostic, Fort Lauderdale, FL) in all groups of mice after 6 hours fast as previously described [15].

At the end of the treatment period, mice were anaesthetized with isoflurane and blood samples were collected from carotid artery into containing heparin tubes. Then, thoracic aorta was harvested immediately, placed in Physiological Salt Solution (PSS, composition in mM: $\mathrm{NaCl} 118 ; \mathrm{KCl} 4.7 ; \mathrm{CaCl}_{2} 2.5 ; \mathrm{KH}_{2} \mathrm{PO}_{4} 1.2 ; \mathrm{MgSO}_{4} \times 7 \mathrm{H}_{2} \mathrm{O} 1.2 ; \mathrm{NaHCO}_{3} 25$ and glucose $11, \mathrm{pH}=7.4$ ) and processed appropriately for further studies.

In other series of experiment, we used 8 weeks-old double knock out between $\mathrm{db}^{-} / \mathrm{db}^{-}$and $\mathrm{p} 50 \mathrm{NF} \kappa \mathrm{B}$ male mice $\left(\mathrm{db}^{-} / \mathrm{db}^{-\mathrm{p} 50 \mathrm{NF} \kappa \mathrm{B}-/-}, \mathrm{n}=5\right)$ and between $\mathrm{db}^{-} / \mathrm{db}^{-}$and PARP-1 male mice $\left(\mathrm{db}^{-} / \mathrm{db}_{-}-\mathrm{PARP}-1-{ }_{-}, \mathrm{n}=5\right)$. The PARP-1 knockout mice were kindly provided by Dr. Alexandar Bishop (Department of Cellular and Structural Biology, University of Texas Health Science Center at San Antonio, San Antonio, TX 78229, USA). The p50NFkB knockout mice were purchased from Jackson laboratory. To generate double knockout, we have bred heterozygote $\mathrm{db}^{-} / \mathrm{db}^{+}$with PARP-1 or p50NFkB knockout mice. Before sacrificing the animals, the body weight and blood glucose levels were measured. Then mice were anaesthetized with isoflurane and then thoracic aortas were immediately harvested and placed in PSS solution and processed appropriately for further studies.

\section{Vascular Reactivity \\ Ex vivo experiments}

Isometric tension recording: Thoracic aorta from control and diabetic mice were carefully cleaned of fat and connective tissue and then cut into rings ( $2 \mathrm{~mm}$ in length) and mounted in a small vessel dual chamber myograph for measurement of isometric tension. After a $30 \mathrm{~min}$ equilibration period in PSS solution bubbled with carbogen, at $37^{\circ} \mathrm{C}$ and $\mathrm{pH}=7.4$, arteries were stretched to their optimal lumen diameter for active tension development. After a second 30 min equilibration period, the vessels were exposed to phenylephrine (PE, $10^{-5} \mathrm{M}$ ) and the presence of functional endothelium was assessed by the ability of acetylcholine (ACh, $10^{-6} \mathrm{M}$ ) to induce relaxation.

To determine the role of eNOS and COX-2 in the impaired endothelium-dependent relaxation in diabetic mice, aortas were incubated with NS $398(10 \mu \mathrm{M})$, a COX-2 selective inhibitor, for $1 \mathrm{~h}$ and then endothelium-dependent relaxation was performed after precontraction with PE.

To determine the role of eNOS and NADPH oxidase in the impaired endothelium-dependent relaxation in diabetic mice, aortas were incubated with L-NAME $(100 \mu \mathrm{M})$ and apocynin $(100 \mu \mathrm{M})$ for 30 minutes and then endothelium-dependent relaxation was performed after pre-contraction with PE. 
The same protocol was used for double knockout $\mathrm{db}^{-} / \mathrm{db}^{-}$and $\mathrm{p} 50 \mathrm{NF \kappa B}$ $\left(\mathrm{db}^{-} / \mathrm{db}^{-\mathrm{p} 50 \mathrm{NF} \mathrm{B}-/-}\right), \mathrm{db}^{-} / \mathrm{db}^{-}$and PARP-1 $\left(\mathrm{db}^{-} / \mathrm{db}^{- \text {PARP-1-/- }}\right)$ male mice. After precontraction with PE $\left(10^{-5} \mathrm{M}\right)$ and the steady maximal contraction, cumulative dose-response curves were obtained for ACh $\left(10^{-8}-10^{-5} \mathrm{M}\right)$ and SNP $\left(10^{-8}-10^{-5} \mathrm{M}\right)$ in the presence or absence of NS-398, L-NAME and apocynin.

In vitro experiments-Thoracic aortas from diabetic mice were carefully cleaned of fat and connective tissue and then cut into rings ( $2 \mathrm{~mm}$ in length) and were mounted in a small vessel dual chamber myograph for measurement of isometric tension. Arteries were incubated with either p65NFkB shRNA lentiviral particle (Santa Cruz, Santa Cruz, CA) to down-regulate p65NFkB expression or AG1478 (LC Laboratories, Woburn, MA), EGFR tyrosine kinase inhibitor for 4 hours. After pre-contraction with $\mathrm{PE}\left(10^{-5} \mathrm{M}\right)$ and the steady maximal contraction, cumulative dose-response curves were obtained for $\mathrm{ACh}\left(10^{-8}-10^{-5}\right.$ $\mathrm{M})$ and SNP $\left(10^{-8}-10^{-5} \mathrm{M}\right)$ in the presence or absence of L-NAME as described above.

\section{Western blot analysis}

Freshly isolated aortas from all groups were immediately frozen in liquid nitrogen and then homogenized in ice-cold lysis buffer as described previously $[14,8]$ Western blot analysis was performed for phosphorylated-Ser1177 and total eNOS (1:1,000 dilution; Cell Signaling, Boston, MA), phosphorylated and total p65NFkB (1:1,000 dilution; Cell Signaling, Boston, MA), cleaved and total PARP-1 (1:1,000 dilution; Cell Signaling, Boston, MA) and COX-2 (1:500 dilution, Santa Cruz, Santa Cruz, CA) using specific antibodies. Blots were stripped and then reprobed with either $\beta$-actin (1:2000 dilution, Santa Cruz, Santa Cruz, CA) or GAPDH (1:2000 dilution, Santa Cruz, Santa Cruz, CA) antibodies to verify the equal loading among the samples.

\section{Drugs}

Phenylephrine hydrochloride, acetylcholine, L-NAME, apocynin, NS398 were obtained from Sigma-Aldrich (St. Louis, MO). IKK-NBD peptide was purchased from Enzo Life sciences (Farmingdale, NY). The DHMEQ was synthesized by Dr. Kazuo Umezawa (Aichi Medical University, Nagakute, Japan).

\section{Statistical analysis}

Results are expressed as mean \pm SEM. Concentration-response curves were analyzed using the GraphPad Prism 4.0 software (GraphPad software, La Jolla, CA). One-way or 2-way ANOVA was used to compare each parameter when appropriate. Comparisons between groups were performed with $t$-tests when the ANOVA test was statistically significant. Values of $P<0.05$ were considered significant. Differences between specified groups were analyzed using the Student's t test (two-tailed) for comparing two groups with $P<0.05$ considered statistically significant. 


\section{RESULTS}

\section{General parameters}

Blood glucose levels and body weight were higher in $\mathrm{db}^{-} / \mathrm{db}^{-}$mice $(393.7 \pm 20.17 \mathrm{mg} / \mathrm{dl}$, $42.29 \pm 0.57 \mathrm{~g}$ respectively) with and without NFKB inhibitors, and in double knockout mice $\left(\mathrm{db}^{-} / \mathrm{db}^{-\mathrm{p} 50 \mathrm{NFkB}-/-}\right.$ and $\left.\mathrm{db}^{-} / \mathrm{db}^{-\mathrm{PARP}-1-/-}\right)$ compared to $\mathrm{db}^{-} / \mathrm{db}^{+}$mice $(132.3 \pm 0.89 \mathrm{mg} / \mathrm{dl}$, $24.19 \pm 0.48$ g respectively) (Table 1).

\section{$\mathrm{NF}_{K B} \mathrm{~B}$ and endothelium-dependent relaxation (EDR) in thoracic aorta}

The endothelium-dependent relaxation (EDR) in thoracic aorta was impaired in $\mathrm{db}^{-} / \mathrm{db}^{-}$ mice compared to $\mathrm{db}^{-} / \mathrm{db}^{+}$mice (Figure 1A, B). Interestingly the inhibition of NFkB improved EDR in thoracic aorta from $\mathrm{db}^{-} / \mathrm{db}^{-}$mice (Figure 1A, B Table 2A). We did not observe any effect on EDR in thoracic aorta in $\mathrm{db}^{-} / \mathrm{db}^{+}$mice after the inhibition of NFKB (Figure 1F). The inhibition of eNOS with L-NAME reduced EDR in all groups of mice (Figure 1E).

Our data demonstrated that the inhibition of NADPH oxidases by apocynin did not affect the EDR in the thoracic aorta (Figure 1C, Table 2B). However, the inhibition of COX-2 by NS398 significantly improved the EDR in thoracic aorta (Figure 1D, Table 2C). Western blot analysis revealed that phosphorylated eNOS was significantly reduced, while phosphorylated NFKB-p65 and cleaved PARP-1 and COX-2 expression were significantly augmented in thoracic aorta from $\mathrm{db}^{-} / \mathrm{db}^{-}$mice (Figure 2A, B, C, D). Interestingly, diabetic mice treated with NFKB inhibitors (DHMEQ and IKK-NBD peptide) enhanced eNOS phosphorylation but reduced NFkB-p65 phosphorylation, cleaved PARP-1 and COX-2 expression (Figure 2A, B, C, D).

To strengthen our results, we examined the EDR in thoracic aorta from double knockout mice $\left(\mathrm{db}^{-} / \mathrm{db}^{-} \mathrm{p}^{50 \mathrm{NFkB}-/-}\right)$. Western blot analysis confirmed the absence of p50NFkB in aorta from $\mathrm{db}^{-} / \mathrm{db}^{-\mathrm{p} 50 \mathrm{NFkB}-/-}$ mice (Figure 3D). Furthermore, our data demonstrated that the EDR was significantly improved in the thoracic aorta isolated from $\mathrm{db}^{-} / \mathrm{db}^{-} \mathrm{p} 50 \mathrm{NF} \kappa \mathrm{B}-/-$ mice associated with increased eNOS phosphorylation (Figure 3A, C Table 2A). In addition we observed that the EDR in thoracic aorta was significantly improved in double knockout $\mathrm{db}^{-} / \mathrm{db}^{-P A R P}-1-/-$ mice and arteries from $\mathrm{db}^{-} / \mathrm{db}^{-}$mice treated with COX-2 inhibitor (Figure $3 \mathrm{~A}, \mathrm{~B}$, Table 2C). These results were also associated with a reduction in cleaved PARP-1 and COX-2 expression in thoracic aorta from $\mathrm{db}^{-} / \mathrm{db}^{-\mathrm{p} 50 \mathrm{NF} k \mathrm{~B}-/-}$ (Figure $3 \mathrm{E}, \mathrm{F}$ ).

Furthermore, western blot analysis revealed that in the thoracic aorta from $\mathrm{db}^{-} / \mathrm{db}^{- \text {PARP-1-l- }}$ mice, PARP-1 was absent and this was associated with reduced $\mathrm{p} 65 \mathrm{NF} \kappa \mathrm{B}$ phosphorylation and COX-2 expression and an increase in eNOS phosphorylation (Figure 3G, H, I, J).

Endothelium-independent relaxation in response to sodium nitroprusside (SNP) in thoracic aorta was similar in all groups (control, $\mathrm{db}^{-} / \mathrm{db}^{-}, \mathrm{db}^{-} / \mathrm{db}^{-}$p50NFkB-/- and $\mathrm{db}^{-} / \mathrm{db}^{-\mathrm{PARP}-1-/-}$ (data not shown) indicating that impaired EDR is related to bioavailability of nitric oxide rather than response of smooth muscle cells to nitric oxide. 


\section{Effect of acute EGFR tyrosine kinase (TK) inhibition and down regulation of p65NF $x B$ on thoracic aorta reactivity}

The acute inhibition of EGFRtk significantly improved the EDR in isolated thoracic aorta from $\mathrm{db}^{-} / \mathrm{db}^{-}$mice (Figure 4A, Table 2D). The $\mathrm{p} 65 \mathrm{NFkB}$ phosphorylation was reduced in thoracic aorta after the inhibition of EGFRtk (Figure 4B) indicating that $\mathrm{p} 65 \mathrm{NF} \kappa \mathrm{B}$ is down stream to EGFRtk. The acute down regulation of $\mathrm{p} 65 \mathrm{NF} \kappa \mathrm{B}$ in isolated aorta from $\mathrm{db}^{-} / \mathrm{db}^{-}$ mice transfected with lentivirus-shRNA-p65NFkB significantly improved the EDR (Figure $4 \mathrm{C}$, Table 2D). Western blot analysis confirmed the down regulation of $\mathrm{p} 65 \mathrm{NF} \kappa \mathrm{B}$ in thoracic aorta transfected with lentivirus-shRNA-p65NFkB (Figure 4D). Endothelium-independent relaxation in response to sodium nitroprusside (SNP) in thoracic aorta showed no difference among groups (control, $\mathrm{db}-/ \mathrm{db}^{-}$and $\mathrm{db}^{-} / \mathrm{db}^{-}$transfected with p65NFkB shRNA lentiviral particles) (data not shown).

\section{DISCUSSION}

In this study, we determined that enhanced NFkB pathway impairs conductance arteries endothelium-dependent relaxation in type 2 diabetic male mice. Thus, the inhibition of $\mathrm{NF \kappa B}$ using pharmacology, molecular and genetic approaches significantly improved EDR in $\mathrm{db}^{-} / \mathrm{db}^{-}$mice. We also delineated that enhanced $\mathrm{NF \kappa B}$ impaired endothelium-dependent relaxation in thoracic aorta by PARP-1 and COX-2-dependent mechanisms. These observations suggest that $\mathrm{NF} \kappa \mathrm{B}$ could be an important target to improve the conductance artery function in type 2 diabetes.

Diabetic vascular dysfunction is a major clinical problem that predisposes patients to a variety of cardiovascular diseases $[16,17,18,19]$. Hyperglycemic episodes play a major part in the development of vascular endothelial dysfunction, which is an early factor preceding the arterial structural wall remodeling [20]. It has been documented that altered cyclooxygenases activity [21], increased oxidative stress levels [22], insulin resistance and inflammation are potentially through the induction of $\mathrm{NF \kappa B}$ [ 23 ]. Although significant progress has been advanced in understanding the importance of $\mathrm{NF \kappa B}$ [24, 25], less is known about NFKB in thoracic aorta endothelial dysfunction in type 2 diabetes.

Endothelium is an important organ regulating the vascular reactivity. Our results indicate that endothelium-dependent relaxation in thoracic aorta, which is highly dependent on the bioavailability of nitric oxide [26], was impaired in type 2 diabetes. These data are in agreement with previous studies [27, 28]. Bussy et al. showed that NFkB activity is increased after loss of nitric oxide [29]. Our data are in accordance with this study since we observed that impairment in endothelial function was associated with an increase in vascular $\mathrm{NF \kappa B}$ activity. Importantly, the inhibition of NFKB activity significantly improved endothelium dependent relaxation in thoracic aorta associated with increased eNOS phosphorylation. The inhibition of NFKB did not affect blood glucose, insulin levels or body weight indicating that enhanced $\mathrm{NF} \kappa \mathrm{B}$ in conductance arteries is a consequence of type 2 diabetes.

Previous studies reported that active NFkB trans-locates into the nucleus, interacts with PARP-1 and binds to DNA [30]. We previously reported that the inhibition of PARP-1 
activity significantly improved vascular function [11] in type 2 diabetes. Moreover, Dr. Veves group's showed activated PARP in subjects at risk for developing type 2 diabetes and impaired vascular reactivity [31]. Furthermore, it has been shown that PARP-1 inhibition exert beneficial effect against the development of cardiovascular complications in type 1 diabetes [32]. Interestingly, the inhibition of NFKB signaling reduced cleaved PARP-1, indicating the cross-talk between NFKB and PARP-1. Our data are in accordance with another study showing that, PARP-1 activation plays an important role in the diabetesinduced death of retinal capillary cells, at least in part via NF-kappaB [32]. Additionally, the inhibition of PARP-1 activity in $\mathrm{db}^{-} / \mathrm{db}^{-}$mice significantly improved vascular function. All together, these data reveal that $\mathrm{NF \kappa B}$ regulates vascular function in type 2 diabetes by PARP-1-dependent mechanism. These data were strengthened with the use of double knockout $\mathrm{db}^{-} / \mathrm{db}^{- \text {PARP-1-l-}}$. Moreover, several studies, supporting our results, demonstrated the formation of a complex between NFKB and PARP-1 in the nucleus, which binds to DNA to modulate gene expression [33].

Another factor that plays an important role in vascular endothelial dysfunction in type 2 diabetes is COX-2. Our data indicate that vascular COX-2 expression was enhanced in thoracic aorta in $\mathrm{db}^{-} / \mathrm{db}^{-}$mice, which is in accordance with previous studies [34, 35]. It is well established that $\mathrm{NF \kappa B}$ controls the expression of genes involved in the inflammatory response, such as COX-2. We observed that the inhibition of NFKB in $\mathrm{db}^{-} / \mathrm{db}^{-}$mice reduced $\mathrm{COX}-2$ expression suggesting that $\mathrm{COX}-2$ is downstream to $\mathrm{NF \kappa} \mathrm{B}$. In addition, our in vitro study showed that acute inhibition of COX-2 improves thoracic aorta endotheliumdependent relaxation in $\mathrm{db}^{-} / \mathrm{db}^{-}$mice. These data indicate that the inhibition of NFkB improved thoracic aorta function by a COX-2-dependent mechanism in $\mathrm{db}^{-} / \mathrm{db}^{-}$mice. The role of COX-2 in vascular dysfunction in diabetes can also be independent of eNOS. Thus, previous studies reported a significant up-regulation of COX-2 in thoracic aortic VSMCs that contributes to enhanced contractile responses likely through TXA2 in type 2 diabetic mice [36]. Our data demonstrated that the inhibition of NFkB reduced COX-2 expression and improved thoracic aorta endothelium-dependent relaxation. These results indicate that COX-2 plays a role in impaired endothelium-dependent relaxation in thoracic aorta in diabetes.

Additionally others and we showed that epidermal growth factor receptor tyrosine kinase (EGFRtk) plays an important role in the regulation of resistance artery myogenic tone. Thus, elevated EGFRtk phosphorylation contributes to resistance arteries dysfunction in type 2 and type 1 diabetes [37, 38]. Our data indicate that in vitro acute inhibition of EGFRtk improved EDR and reduced $\mathrm{p} 65 \mathrm{NF} \kappa \mathrm{B}$ phosphorylation, indicating that EGFRtk is upstream to NFkB.

In conclusion, our in vivo and in vitro data clearly indicate that enhanced NFkB pathway impairs thoracic aorta endothelium-dependent relaxation in type 2 diabetes. We also previously demonstrated that augmented NFkB impairs resistance arteries endotheliumdependent relaxation in type 2 diabetic mice. Taken all together these evidences indicate that the $\mathrm{NF \kappa B}$ pathway is not specific to one vascular bed and could be a potential target for a novel therapeutic strategy to reverse diabetes-induced vascular complication. Figure 5 showed the proposed mechanism by which enhanced NFKB causes endothelial dysfunction in thoracic aorta in type 2 diabetes. 


\section{PERSPECTIVES}

Type 2 diabetes is a metabolic disease, characterized by hyperglycemia and insulin resistance, associated with vascular dysfunction. Diabetes induced-vascular complication is still growing. Therefore, the development of novel effective treatments for diabetic patients with vascular complications remains critical. Our data indicate that NFkB plays an important role in vascular dysfunction in type 2 diabetic mice. Importantly, the inhibition of NFkB activity improved vascular function by PARP-1 and COX-2 dependent mechanisms. Therefore, NFkB and its down stream signaling (PARP-1 and COX-2) could be potential targets for novel therapeutic strategies to overcome diabetes-induced vascular complications.

\section{LIMITATION}

The endothelial nitric-oxide synthase (eNOS) activity is regulated by multiple phosphorylation sites. The coordinated phosphorylation of eNOS at Ser1177 and dephosphorylation at Thr495 activates the enzyme, whereas inhibition results when Thr495 is phosphorylated and Ser1177 is dephosphorylated. However, Ser1177 can be phosphorylated along with other inhibitory residues that prevent the enzyme from being active and as consequence it reduces the amount of NO bioavailability. Recently other phosphorylation sites of eNOS have been reported, including the stimulatory Ser 635, Ser 617 sites, and the inhibitory Thr 495 and Ser 116 sites. Therefore, the eNOS phosphorylation should be associated with the measurement of NO bioavailability and vascular endothelium-dependent relaxation.

Another limitation of this work is the use of genetic model mouse $\left(\mathrm{db}^{-} / \mathrm{db}^{-}\right)$. The human diabetes is typically a result of obesity, sedentary lifestyle, and uncontrolled diet. Dietinduced obesity and/or diabetes would be a more representative model. Therefore, the role of $\mathrm{NF \kappa B}$ inhibition in mice fed with diet-induced obesity/diabetes is needed.

\section{Acknowledgements}

N/A

Sources of Funding

We acknowledge grant support from National Institutes of Health (1R01HL095566; PI: Dr. Matrougui) and (5R01HL097111; PI: Dr. Trebak)

\section{REFERENCES}

1. Ruderman NB, Williamson JR, Brownlee M. Glucose and diabetic vascular disease. FASEB J. 1992; 6(11):S2905-2914.

2. Cosentino F, Lüscher TF. Endothelial dysfunction in diabetes mellitus. J Cardiovasc Pharmacol. 1998; 32(3):S54-61. [PubMed: 9883749]

3. Creager MA, Lüscher TF, Cosentino F, Beckman JA. Diabetes and vascular disease: pathophysiology, clinical consequences, and medical therapy: Part I. Circulation. 2003; 108:15271532. [PubMed: 14504252]

4. Harrison DG. Cellular and molecular mechanisms of endothelial cell dysfunction. J Clin Invest. 1997; 100(9):2153-2177. [PubMed: 9410891] 
5. Yang Z, Ming XF. Recent advances in understanding endothelial dysfunction in atherosclerosis. Clin Med Res. 2006; 4(1):53-65. [PubMed: 16595793]

6. Guijarro C, Egido J. Transcription factor-kappa B (NF-kappa B) and renal disease. Kidney Int. 2001; 59(2):415-424. [PubMed: 11168923]

7. Shanmugam N, Gaw Gonzalo IT, Natarajan R. Molecular mechanisms of high glucose-induced cyclooxygenase-2 expression in monocytes. Diabetes. 2004; 53(3):795-802. [PubMed: 14988266]

8. Crofford LJ, Tan B, McCarthy CJ, Hla T. Involvement of nuclear factor kappa B in the regulation of cyclooxygenase-2 expression by interleukin-1 in rheumatoid synoviocytes. Arthritis Rheum. 1997; 40(2):226-236. [PubMed: 9041934]

9. Charalambous MP, Lightfoot T, Speirs V, Horgan K, Gooderham NJ. Expression of COX-2, NFkappaB-p65, NF-kappaB-p50 and IKKalpha in malignant and adjacent normal human colorectal tissue. Br J Cancer. 2009; 101(1):106-115. [PubMed: 19513071]

10. Hassa PO, Haenni SS, Buerki C, Meier NI, Lane WS, Owen H, Gersbach M, Imhof R, Hottiger MO. Acetylation of poly(ADP-ribose) polymerase-1 by p300/CREB-binding protein regulates coactivation of NF-kappaB-dependent transcription. J Biol Chem. 2005; 280(49):40450-40464. [PubMed: 16204234]

11. Choi SK, Galán M, Kassan M, Partyka M, Trbak M, Matrougui M. Poly(ADP-Ribose) Polymerase 1 Inhibition Improves Coronary Arteriole Function in Type 2 Diabetes Mellitus. Hypertension. 2012; 59(5):1060-1068. [PubMed: 22454481]

12. Soriano FG, Pacher P, Mabley J, Liaudet L, Szabó C. Rapid reversal of the diabetic endothelial dysfunction by pharmacological inhibition of poly(ADP-ribose) polymerase. Circ Res. 2001; 89:684-691. [PubMed: 11597991]

13. Pacher P, Szabó C. Role of poly(ADP-ribose) polymerase-1 activation in the pathogenesis of diabetic complications: endothelial dysfunction, as a common underlying theme. Antioxid Redox Signal. 2005; 7:1568-1580. [PubMed: 16356120]

14. Kassan M, Choi SK, Galan M, Bishop A, Umezawa K, Trebak M, Belmadani S, Matrougui K. Enhanced NFkB Activity Impairs Vascular Function through PARP-1, SP-1 and COX2-Dependent Mechanisms in Type 2 Diabetes. Diabetes. 2013 doi: 10.2337/db12-1374.

15. Choi SK, Galán M, Partyka M, Trebak M, Belmadani S, Matrougui K. Chronic inhibition of epidermal growth factor receptor tyrosine kinase and extracellular signal-regulated kinases 1 and 2 (ERK1/2) augments vascular response to limb ischemia in type 2 diabetic mice. Am J Pathol. 2012; 180(1):410-418. [PubMed: 22067908]

16. Schalkwijk CG, Stehouwer CD. Vascular complications in diabetes mellitus: the role of endothelial dysfunction. Clin Sci (Lond). 2005; 109(2):143-59. [PubMed: 16033329]

17. Maser RE, Mitchell BD, Vinik AI, Freeman R. The association between cardiovascular autonomic neuropathy and mortality in individuals with diabetes: a meta-analysis. Diabetes Care. 2003; 26(6):1895-1901. [PubMed: 12766130]

18. Laing SP, Swerdlow AJ, Slater SD, Burden AC, Morris A, Waugh NR, Gatling W, Bingley PJ, Patterson CC. Mortality from heart disease in a cohort of 23,000 patients with insulin-treated diabetes. Diabetologia. 2003; 46(6):760-765. [PubMed: 12774166]

19. Haffner SM, Lehto S, Rönnemaa T, Pyörälä K, Laakso M. Mortality from coronary heart disease in subjects with type 2 diabetes and in nondiabetic subjects with and without prior myocardial infarction. N Engl J Med. 1998; 339(4):229-234. [PubMed: 9673301]

20. Tooke JE, Goh KL. Vascular function in Type 2 diabetes mellitus and pre-diabetes: the case for intrinsic endotheiopathy. Diabet Med. 1999; 16(9):710-715. [PubMed: 10510946]

21. Sánchez A, Contreras C, Martínez P, Villalba N, Benedito S, Garcia-Sacristan A, Salaices M, Hernandez M, Prieto D. Enhanced cyclooxygenase 2-mediated vasorelaxation in coronary arteries from insulin-resistant obese Zucker rats. Atherosclerosis. 2010; 213(2):392-399. [PubMed: 20956003]

22. Schuhmacher S, Oelze M, Bollmann F, Kleinert H, Otto C, Heeren T, Steven S, Hausding M, Knorr M, Pautz A, Reifenberg K, Schulz E, Gori T, Wenzel P, Munzel T, Daiber A. Vascular dysfunction in experimental diabetes is improved by pentaerithrityl tetranitrate but not isosorbide-5-mononitrate therapy. Diabetes. 2011; 60(10):2608-2616. [PubMed: 21844097] 
23. Natali A, Toschi E, Baldeweg S, Ciociaro D, Favilla S, Sacca L, Ferrannini E. Clustering of insulin resistance with vascular dysfunction and low-grade inflammation in type 2 diabetes. Diabetes. 2006; 55(4):1133-1140. [PubMed: 16567539]

24. Lorenzo O, Picatoste B, Ares-Carrasco S, Ramirez E, Egido J, Tunon J. Potential role of nuclear factor $\mathrm{kB}$ in diabetic cardiomyopathy. Mediators Inflamm. 2011; 2011:652097. [PubMed: 21772665]

25. Rodríguez-Ayala E, Anderstam B, Suliman ME, Seeberger A, Heimburger O, Lindholm B, Stenvinkel P. Enhanced RAGE-mediated NFkappaB stimulation in inflamed hemodialysis patients. Atherosclerosis. 2005; 180(2):333-340. [PubMed: 15910860]

26. Moncada S, Higgs A. The L-arginine-nitric oxide pathway. N Engl J Med. 1993; 329(27):20022012. [PubMed: 7504210]

27. Palen DI, Matrougui K. Role of elevated EGFR phosphorylation in the induction of structural remodelling and altered mechanical properties of resistance artery from type 2 diabetic mice. Diabetes Metab Res Rev. 2008; 24(8):651-656. [PubMed: 18973206]

28. Su J, Lucchesi PA, Gonzalez-Villalobos RA, Palen DI, Rezk BM, Suzuki Y, Boulares HA, Matrougui K. Role of advanced glycation end products with oxidative stress in resistance artery dysfunction in type 2 diabetic mice. Arterioscler Thromb Vasc Biol. 2008; 28(8):1432-1438. [PubMed: 18483403]

29. Zeiher AM, Fisslthaler B, Schray-Utz B, Busse R. Nitric oxide modulates the expression of monocyte chemoattractant protein 1 in cultured human endothelial cells. Circ Res. 1995; 76(6): 980-986. [PubMed: 7758169]

30. Zerfaoui M, Errami Y, Naura AS, Suzuki Y, Kim H, Ju J, Liu T, Hans CP, Kim JG, Abd Elmageed ZY, Koochekpour S, Catling A, Boulares AH. Poly(ADP-ribose) polymerase-1 is a determining factor in Crm1-mediated nuclear export and retention of p65 NF-kappa B upon TLR4 stimulation. J Immunol. 2010; 185(3):1894-1902. [PubMed: 20610652]

31. Szabó C, Zanchi A, Komjáti K, Pacher P, Krolewski AS, Quist WC, LoGerfo FW, Horton ES, Veves A. Poly(ADP-Ribose) polymerase is activated in subjects at risk of developing type 2 diabetes and is associated with impaired vascular reactivity. Circulation. 2002; 106:2680-2686. [PubMed: 12438293]

32. Pacher P, Liaudet L, Soriano FG, Mabley JG, Szabó E, Szabó C. The role of poly(ADP-ribose) polymerase activation in the development of myocardial and endothelial dysfunction in diabetes. Diabetes. 2002; 51:514-521. [PubMed: 11812763]

33. Ménissier de Murcia J, Ricoul M, Tartier L, Niedergang C, Huber A, Dantzer F, Schreiber V, Ame JC, Dierich A, Le Meur M, Sabatier L, Chambon P, de Murcia G. Functional interaction between PARP-1 and PARP-2 in chromosome stability and embryonic development in mouse. EMBO J. 2003; 22(9):2255-2263. [PubMed: 12727891]

34. Bagi Z, Erdei N, Toth A, Hintze TH, Koller A, Kaley G. Type 2 diabetic mice have increased arteriolar tone and blood pressure: enhanced release of COX-2-derived constrictor prostaglandins. Arterioscler Thromb Vasc Biol. 2005; 25(8):1610-1616. [PubMed: 15947245]

35. Zhang J, Lei T, Chen X, Peng Y, Long H, Zhou L, Huang J, Chen Z, Long Q, Yang Z. Resistin upregulates COX-2 expression via TAK1-IKK-NF-kappaB signaling pathway. Inflammation. 2010; 33(1):25-33. [PubMed: 19774455]

36. Guo Z, Su W, Allen S, Pang H, Daugherty A, Smart E, Gong MC. COX-2 up-regulation and vascular smooth muscle contractile hyperreactivity in spontaneous diabetic $\mathrm{db} / \mathrm{db}$ mice. Cardiovasc Res. 2005; 67(4):723-735. [PubMed: 15885672]

37. Belmadani S, Palen DI, Gonzalez-Villalobos RA, Boulares HA, Matrougui K. Elevated epidermal growth factor receptor phosphorylation induces resistance artery dysfunction in diabetic $\mathrm{db} / \mathrm{db}$ mice. Diabetes. 2008; 57(6):1629-1637. [PubMed: 18319304]

38. Benter IF, Yousif MH, Griffiths SM, Benboubetra M, Akhtar S. Epidermal growth factor receptor tyrosine kinase-mediated signalling contributes to diabetes-induced vascular dysfunction in the mesenteric bed. Br J Pharmacol. 2005; 145(6):829-836. [PubMed: 15852031] 

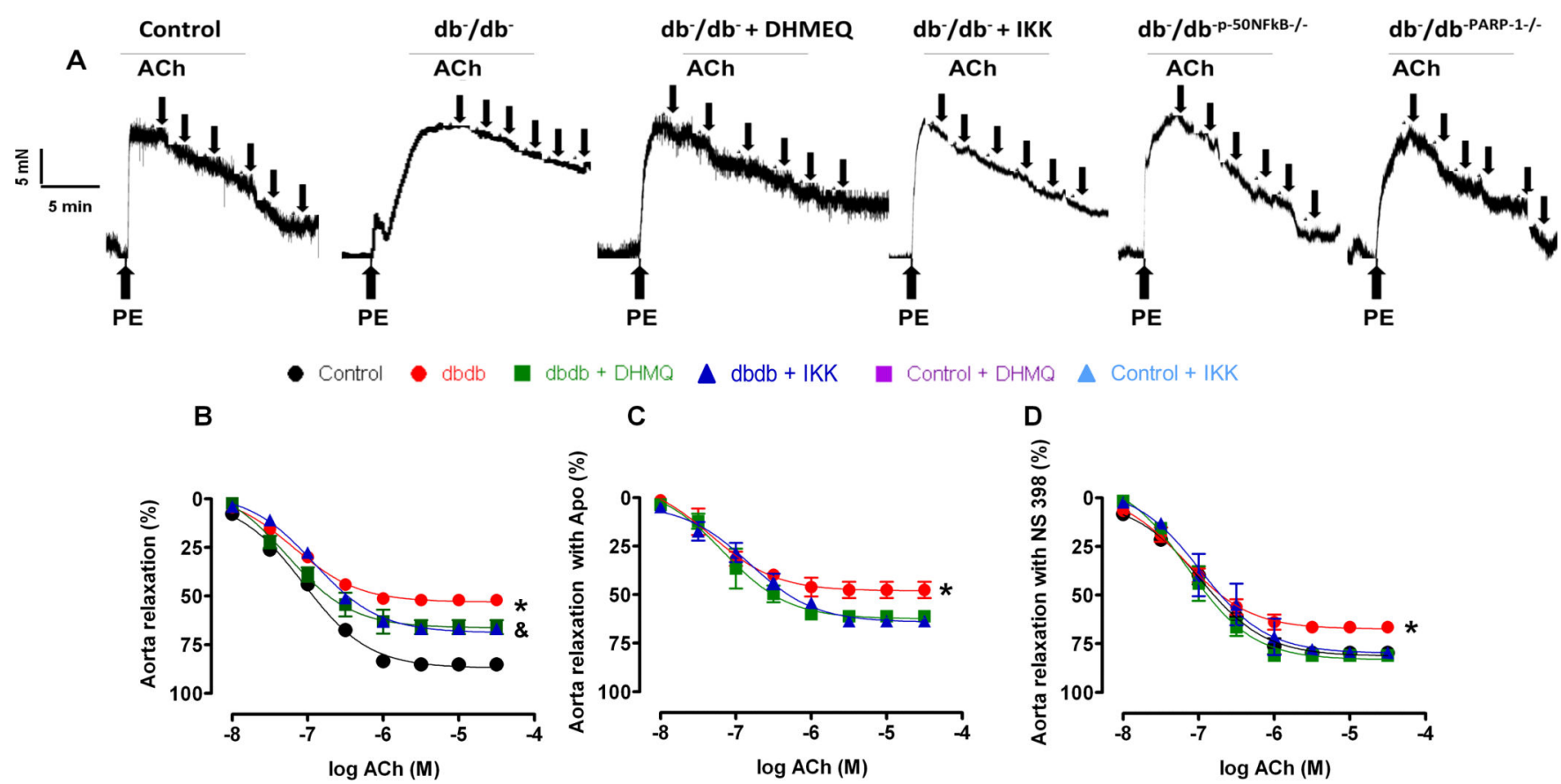

E
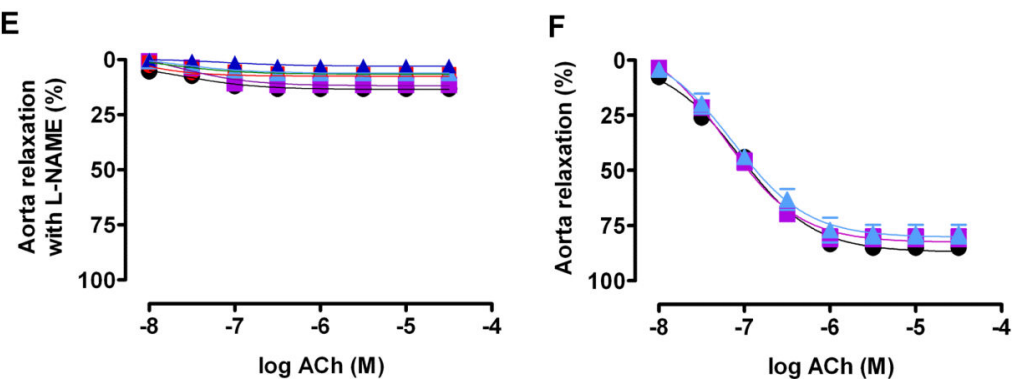

Figure 1. Effect of the $N F \kappa B$ inhibition on endothelium-dependent relaxation in thoracic aorta $(\mathbf{n}=10)$

Key representative traces showing endothelium-dependent relaxation curves to ACh from control, and type 2 diabetic mice $\left(\mathrm{db}^{-} / \mathrm{db}^{-}\right)$treated with or without DHMEQ or IKK-NBD peptide and double knockout mice between $\mathrm{db}^{-} / \mathrm{db}^{-}$and $\mathrm{p}-50 \mathrm{NF \kappa B}\left(\mathrm{db}^{-} / \mathrm{db}^{-\mathrm{p}-50 \mathrm{NFkB}-/-}\right)$ and double knockout mice between $\mathrm{db}^{-} / \mathrm{db}^{-}$and PARP-1 male mice $\left(\mathrm{db}^{-} / \mathrm{db}^{-\mathrm{PARP}-1-{ }^{-}}\right)$(A). Endothelium-dependent relaxation in response to cumulative doses of $\mathrm{ACh}\left(10^{-8}-3.10^{-5} \mathrm{M}\right)$ in rings from aorta, pre-contracted with phenylephrine ( $\left.\mathrm{PE}, 10^{-5} \mathrm{M}\right)$, from control, $\mathrm{db}^{-} / \mathrm{db}^{-}$ treated with or without DHMEQ or IKK-NBD peptide $(\mathbf{B})$ and incubated with apocynin (APO, NADPH oxidase inhibitor) (C) or NS 398 (COX-2 inhibitor) (D) or L-NAME (eNOS inhibitor) (E). Control, control treated with or without DHMEQ or IKK-NBD peptide (F). $* \mathrm{P}<0.05$ for $\mathrm{db}^{-} / \mathrm{db}^{-}$vs. control, $\mathrm{db}^{-} / \mathrm{db}^{-}$treated with DHMEQ or IKK-NBD. \&P $<0.05$ for $\mathrm{db}^{-} / \mathrm{db}^{-}$treated with DHMEQ or IKK-NBD vs. control. 

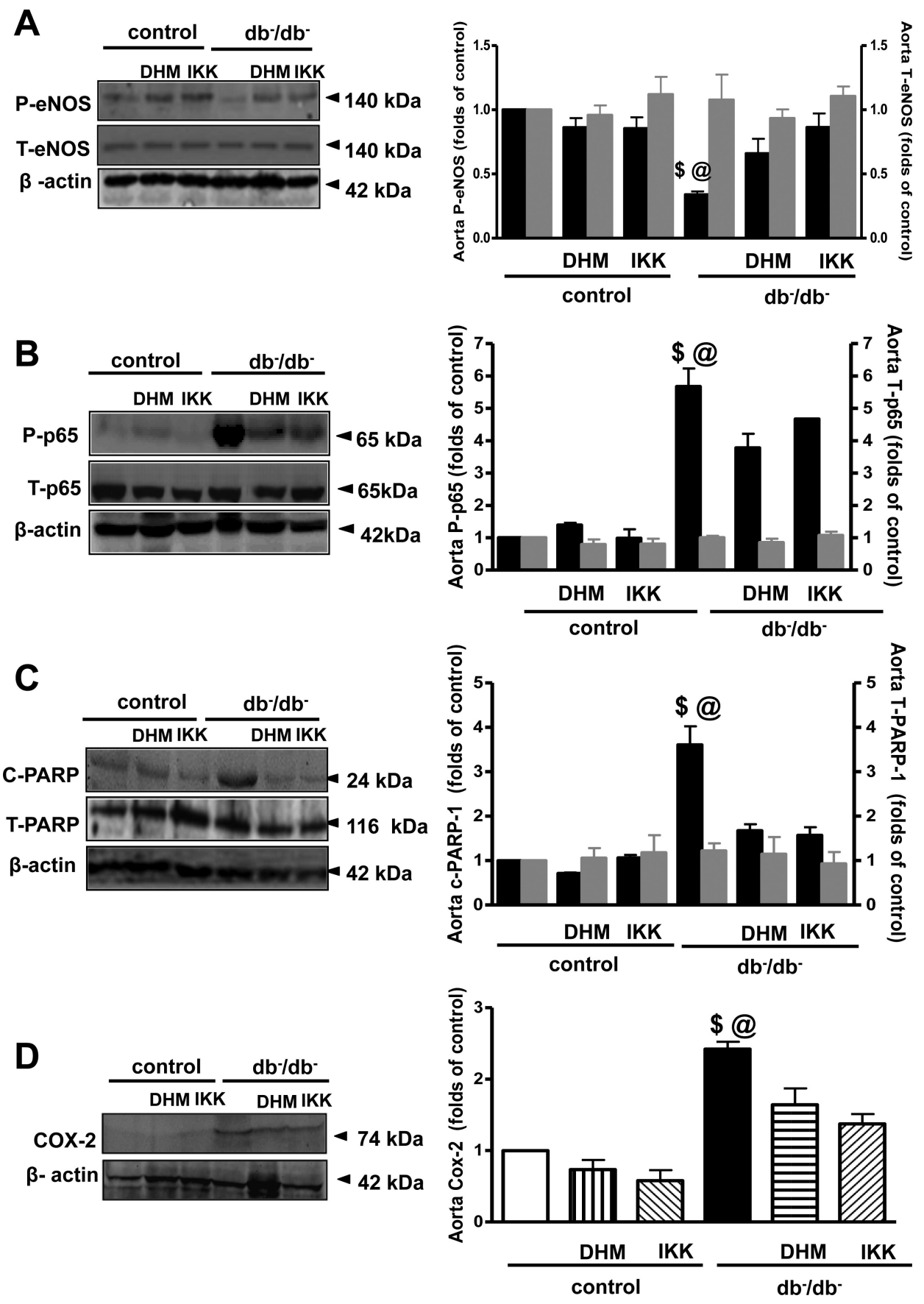

Figure 2.

Western blot analysis and quantitative data $(\mathbf{n}=5)$, in homogenized aorta from control and type 2 diabetic mice $\left(\mathrm{db}^{-} / \mathrm{db}^{-}\right)$treated with or without DHMEQ or IKK-NBD, showing phosphorylated P-eNOS, total T-eNOS (A) phosphorylated P-p-65, total T-p-65 (B), cleaved c-PARP-1 and total T-PARP-1 (C), COX-2 (D) and $\beta$-actin. ${ }^{\$} \mathrm{P}<0.05$ for $\mathrm{db}^{-} / \mathrm{db}^{-}$vs. control, control treated with DHMEQ or IKK-NBD, $\mathrm{db}^{-} / \mathrm{db}^{-}$treated with DHMEQ or IKK-NBD.

${ }^{\circledR} \mathrm{P}<0.05$ for $\mathrm{db}^{-} / \mathrm{db}^{-}$vs. $\mathrm{db}^{-} / \mathrm{db}^{-}$treated with DHMEQ or IKK-NBD 

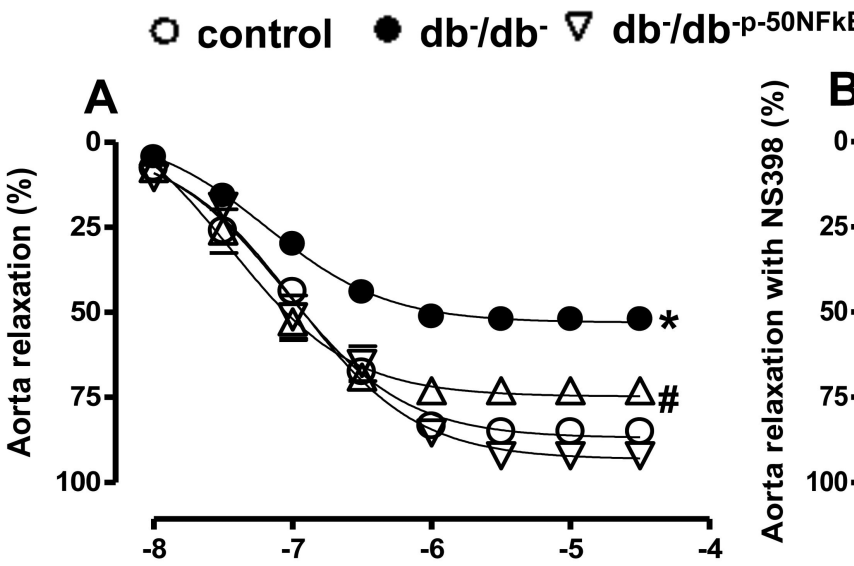

$\Delta \mathrm{db} / \mathrm{db}-\mathrm{PARP}-1-/-$
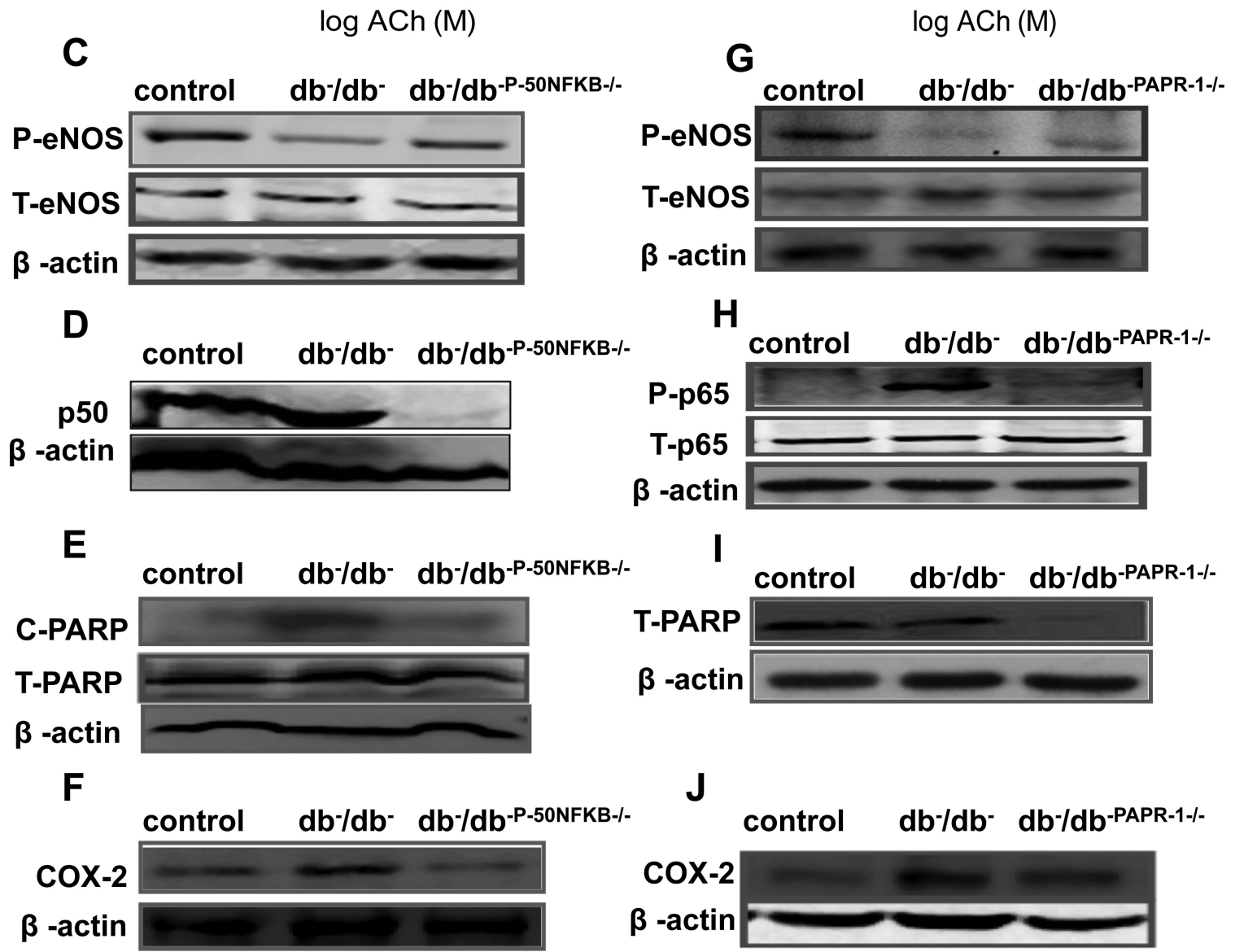

Figure 3. Effect of the $N F \kappa B$ inhibition on endothelium-dependent relaxation in thoracic aorta $(\mathbf{n}=10)$

Endothelium-dependent relaxation in response to cumulative doses of $\mathrm{ACh}\left(10^{-8}-3.10^{-5} \mathrm{M}\right)$ in rings from aorta, pre-contracted with phenylephrine (PE, $\left.10^{-5} \mathrm{M}\right)$, from Control, $\mathrm{db}^{-} / \mathrm{db}^{-}$,

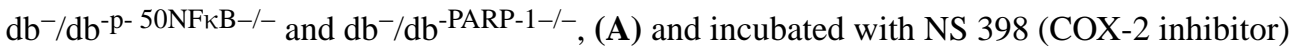
(B) $* \mathrm{P}<0.05$ for $\mathrm{db}^{-} / \mathrm{db}^{-}$vs. control, $\mathrm{db}^{-} / \mathrm{db}^{-\mathrm{p}-50 \mathrm{NF} \mathrm{B}-/-}$ or $\mathrm{db}^{-} / \mathrm{db}^{-\mathrm{PARP}-1-/-\#} \mathrm{P}<0.05$ for $\mathrm{db}^{-} / \mathrm{db}^{-\mathrm{PARP}-1}$ vs. control, $\mathrm{db}^{-} / \mathrm{db}^{\mathrm{p}-50 \mathrm{NF} \kappa \mathrm{B}-/-}$.

Western blot analysis and quantitative data $(n=5)$ in homogenized thoracic aorta from control, $\mathrm{db}^{-} / \mathrm{db}^{-}$, and double knockout mice between $\mathrm{db}^{-} / \mathrm{db}^{-}$and $\mathrm{p} 50 \mathrm{NF} \kappa \mathrm{B}$ 
$\left(\mathrm{db}^{-} / \mathrm{db}^{-\mathrm{p}-50 \mathrm{NF} \kappa \mathrm{B}-/-}\right)$ showing phosphorylated (P)-eNOS, total (T)-eNOS (C) p50NFkB (D), cleaved (c)-PARP-1 and total (T)-PARP-1 (E), COX-2 (F) and $\beta$-actin, and double knockout mice between $\mathrm{db}^{-} / \mathrm{db}^{-}$and PARP-1 male mice $\left(\mathrm{db}^{-} / \mathrm{db}^{-\mathrm{PARP}-1---}\right)$, showing phosphorylated (P)-eNOS, total (T)-eNOS (G) phosphorylated (P)-p-65 and total (T)-p-65 (H), total (T)PARP-1 (I), COX-2 (J) and $\beta$-actin. 

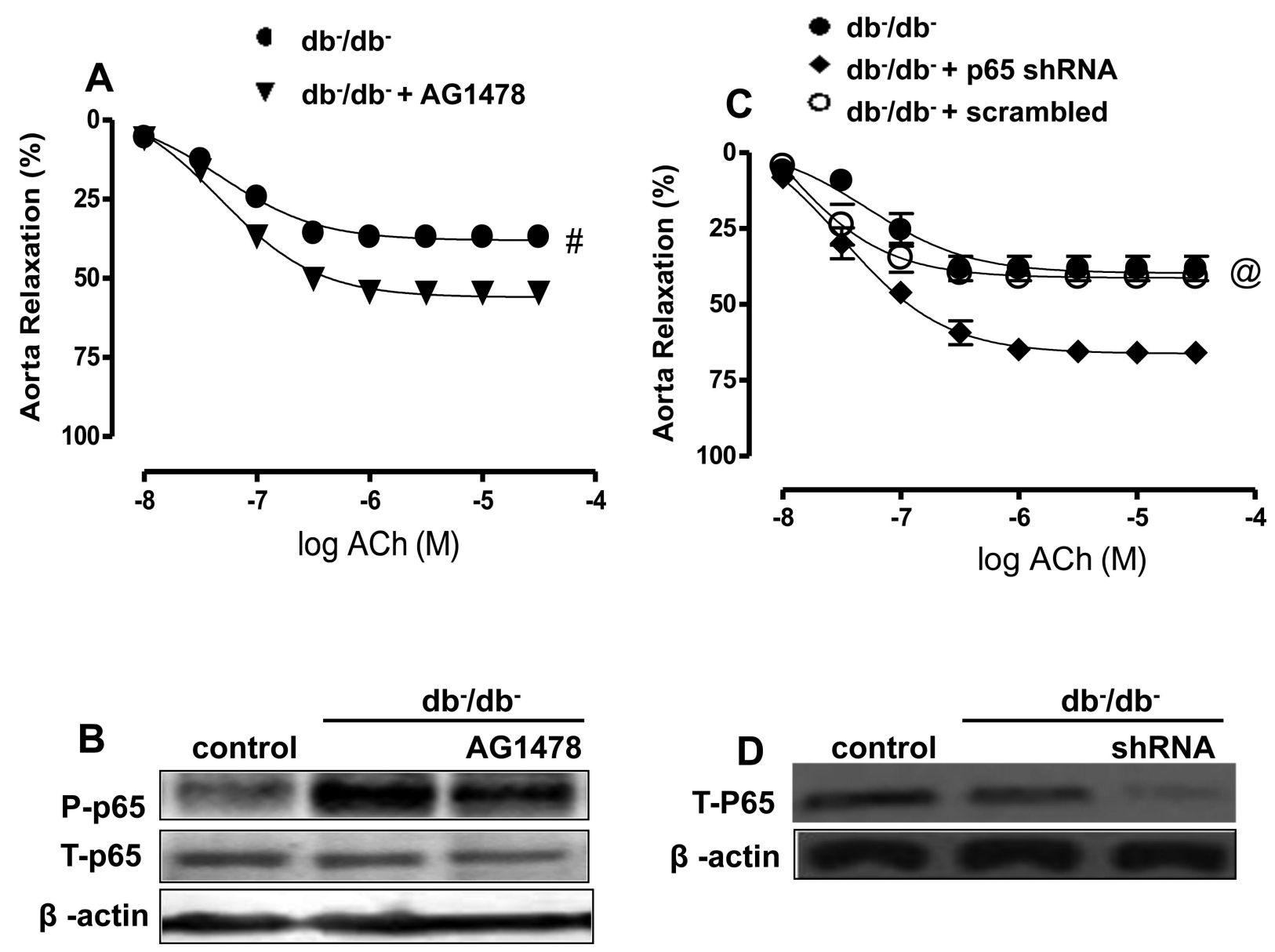

Figure 4. Effect of the EGFRtk inhibitor and p-65NF $\kappa B$ shRNA lenti-viral particles $(n=5)$ on -Endothelium-dependent relaxation in thoracic aorta in response to cumulative doses of ACh $\left(10^{-8}-3 \cdot 10^{-5} \mathrm{M}\right)$ in rings from aorta, pre-contracted with phenylephrine (PE, $\left.10^{-5} \mathrm{M}\right)$, from $\mathrm{db}^{-} / \mathrm{db}^{-}$incubated with either AG1478 (EGFRtk inhibitor) or p-65NF $\kappa \mathrm{B}$ shRNA lenti-viral

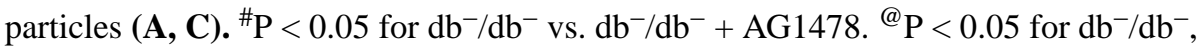
$\mathrm{db}^{-} / \mathrm{db}^{-}+$scrambled vs. $\mathrm{db}-/ \mathrm{db}^{-}+\mathrm{P} 65$ shRNA

Western blot analysis and quantitative data $(\mathbf{n = 5})$ in homogenized thoracic aorta from $\mathrm{db}^{-} /$ $\mathrm{db}^{-}$incubated with either AG1478 (EGFRtk inhibitor) or p-65NF $\kappa$ B shRNA lenti-viral particles, showing P-p-65, T-p-65 (B, D) and $\beta$-actin. 


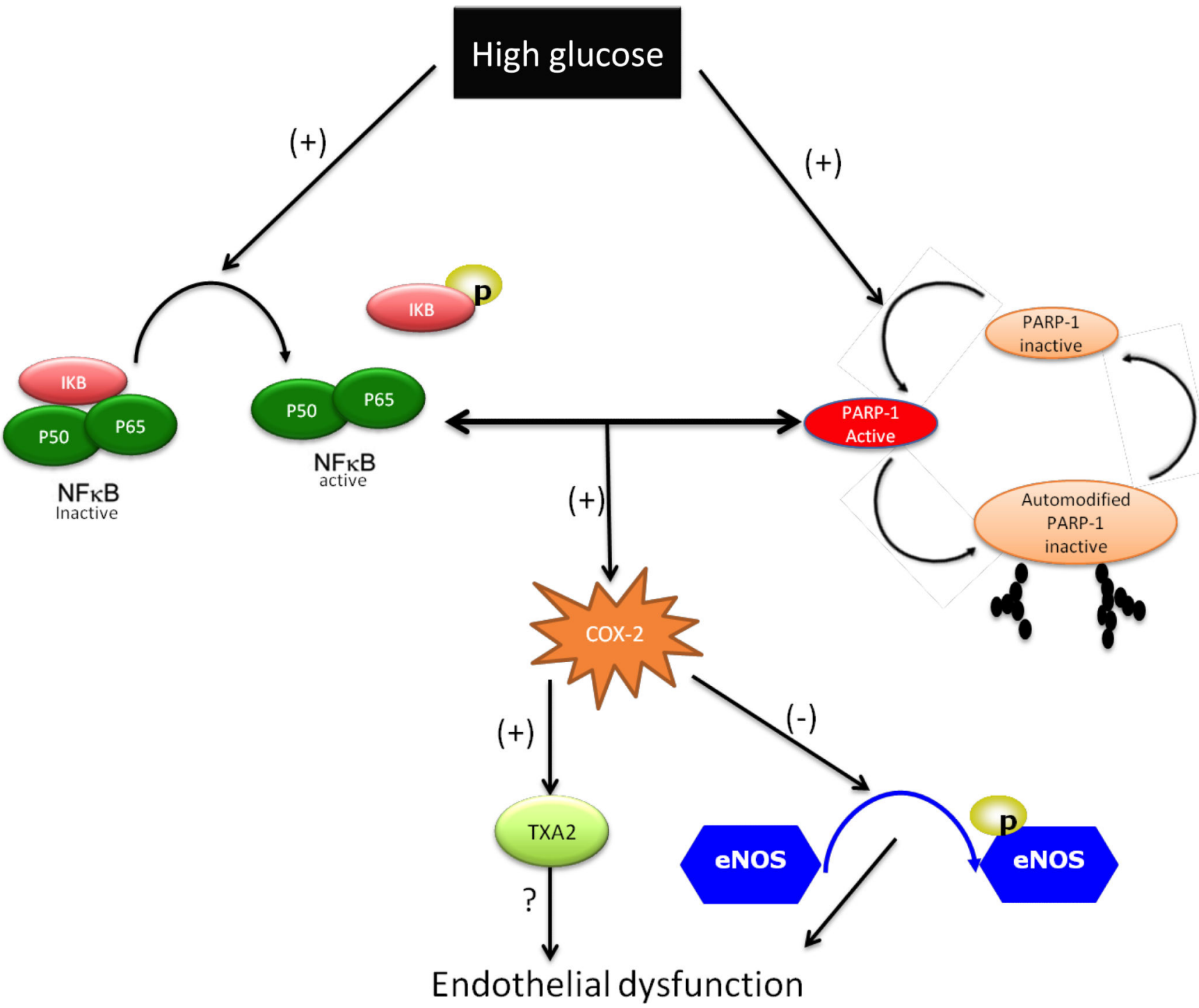

Figure 5.

Representative schematic diagram of the proposed mechanism by which NFkB impairs thoracic aorta endothelium-dependent relaxation in type 2 diabetic mice. 

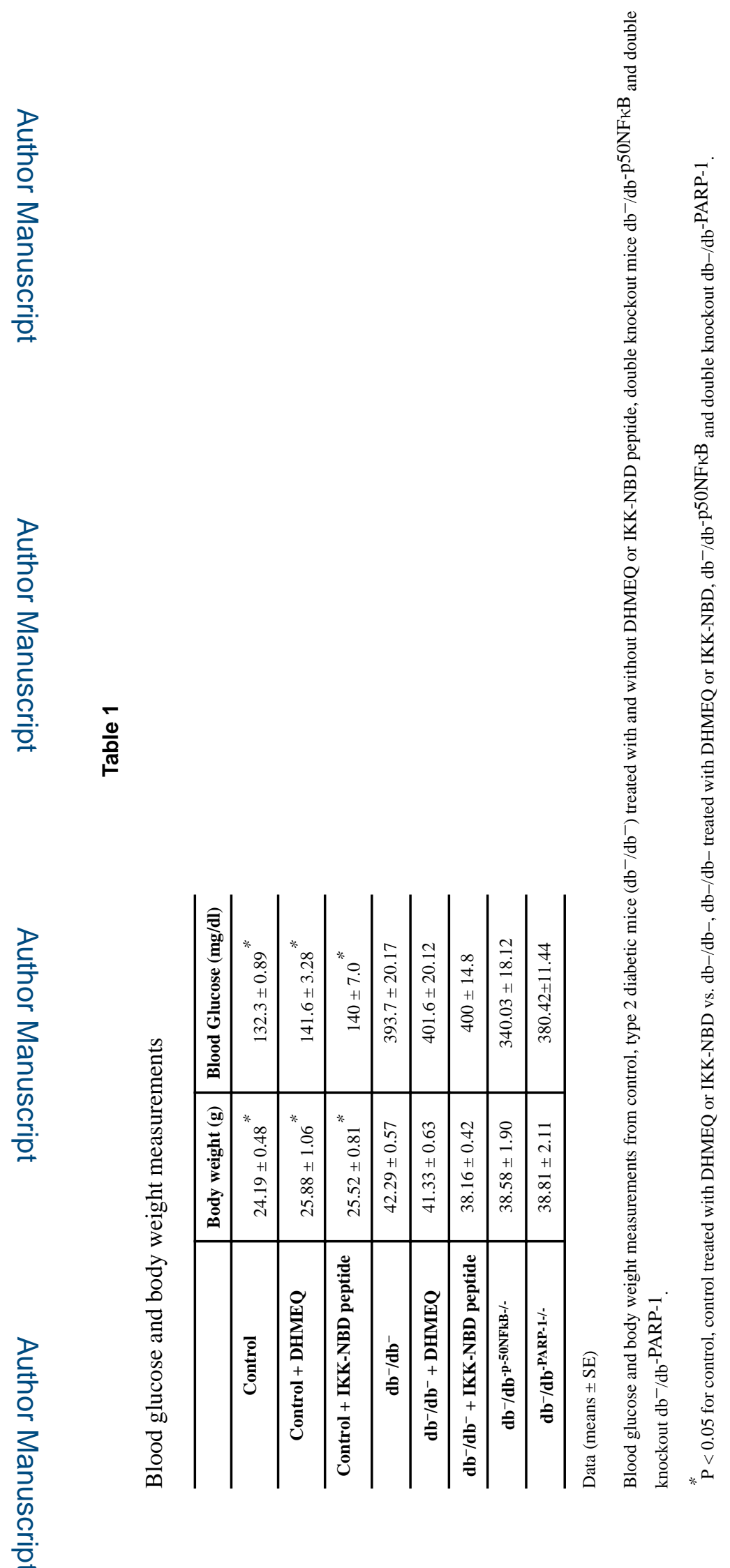

Diabetes Metab Res Rev. Author manuscript; available in PMC 2016 April 12. 


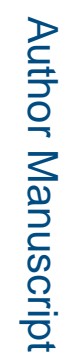

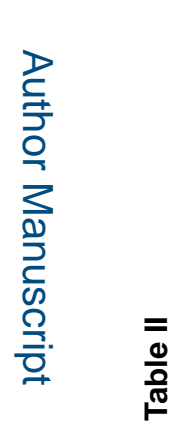
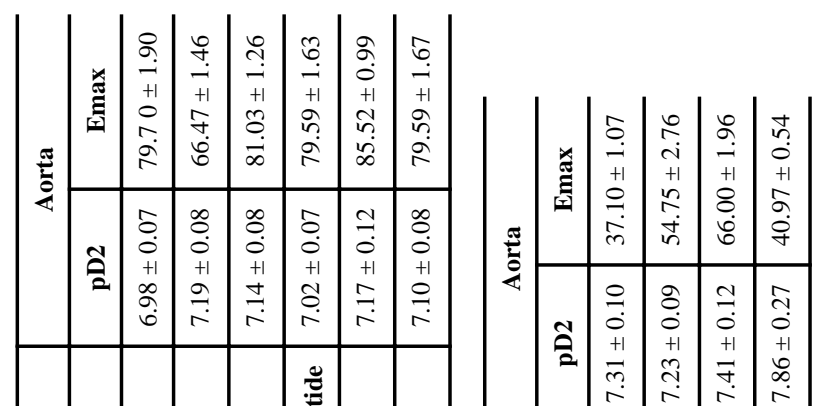

$\overline{0}$
$\frac{\overline{0}}{0}$
0
$\frac{7}{0}$
0
0
$\frac{0}{0}$
$\overline{0}$

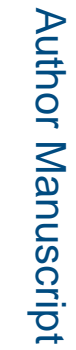
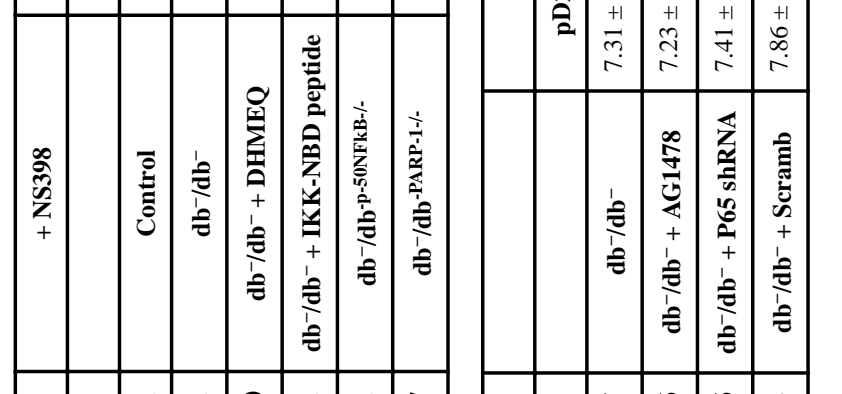

章

?

ह

.

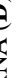

势

$\frac{10}{20}$

है

害

คิ

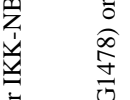

苟

记黄

言竞

㞸

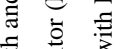

黄泀

ฮँ

กิ

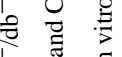

है ิิ

茴全

高

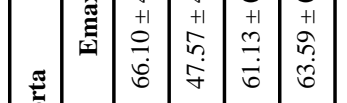

त.

के क्षे

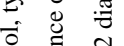

苛芯

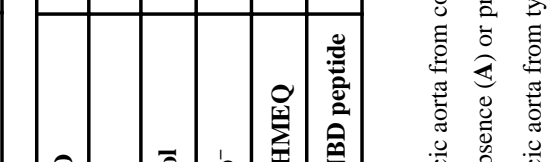

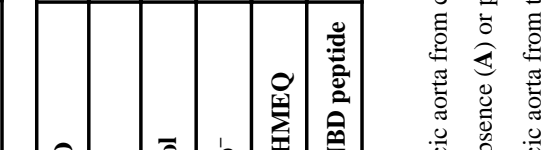

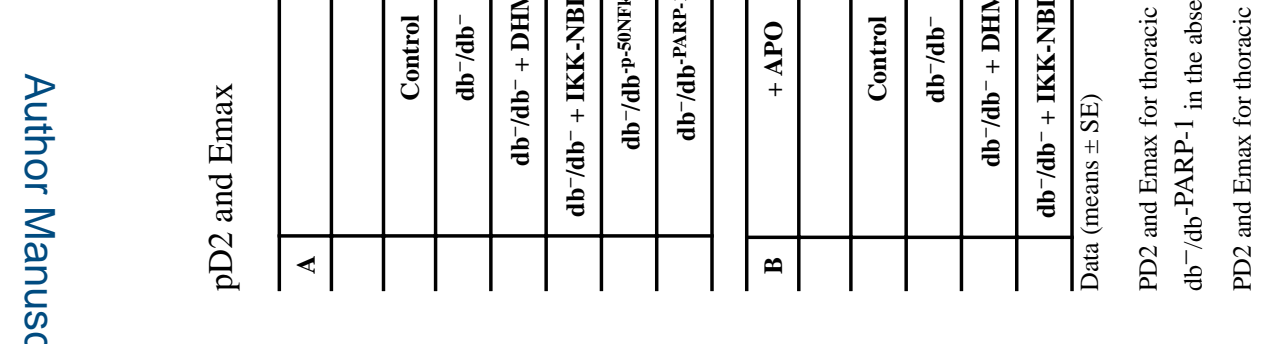

Diabetes Metab Res Rev. Author manuscript; available in PMC 2016 April 12. 